\title{
LERNAEENICUS QUADRILOBATUS N. SP. (COPEPODA, LERNAEIDAE) PARASITIC ON THE LANTERN-FISH DIAPHUS COERULEUS
}

\section{AUTHOR(S):}

Yamaguti, Satyu; Utinomi, Huzio

\section{CITATION:}

Yamaguti, Satyu .... [et al]. LERNAEENICUS QUADRILOBATUS N. SP. (COPEPODA,

LERNAEIDAE) PARASITIC ON THE LANTERN-FISH DIAPHUS COERULEUS. PUBLICATIONS OF THE SETO MARINE BIOLOGICAL LABORATORY 1953, 3(1): $51-53$

\section{ISSUE DATE:}

1953-07-30

URL:

http://hdl.handle.net/2433/174461

RIGHT: 


\title{
LERNAEENICUS QUADRILOBATUS N. SP. (COPEPODA, LERNAEIDAE) PARASITIC ON THE LANTERN-FISH DIAPHUS COERULEUS*
}

\author{
SATYŪ YAMAGUTI \\ Zoological Institute, Kyoto University, Kyoto \\ AND \\ Huzio UTINOMI \\ Seto Marine Biological Laboratory, Sirahama
}

With one Text-figure

A single gravid female of this species was found on a lantern-fish, Diaphus coeruleus Klunzinger caught by Mr. S. URA of the Seto Laboratory in Tanabe Bay on November 16,1952 , with its cephalothorax and neck completely embedded in the flesh on the right side between the operculum and the dorsal fin.

Holotype: A gravid female. Reg. No. 120, preserved in the museum of the Seto Marine Biological Laboratory.

Body divided into cephalothorax, neck, trunk and abdomen, $17.1 \mathrm{~mm}$ in total length. Cephalothorax : $1.8 \mathrm{~mm}$ long by $2.1 \mathrm{~mm}$ broad; head end broadly rounded, with dark purple spots of irregular outline behind base of antennae, and a median eye-spot $0.35 \mathrm{~mm}$ posterior to frontal margin. On either side of the cephalothorax there are two rounded protuberances one directly behind the other, the larger anterior measuring about $0.9 \mathrm{~mm}$ and the posterior about $0.75 \mathrm{~mm}$ in diameter at the base.

On the dorsal aspect the head proper is separated on each side from the above-mentioned lateral lobe by an outwardly convex longitudinal groove, and completely fused with the first thoracic segment, whose conical posterolateral corner bears a minute blunt-pointed papilliform projection; the second, third and fourth thoracic segments are clearly indicated by their prominent chitinous dorsolateral ridges, whose posterior corner is rounded in the second and third segments but produced into a conical tooth in the fourth segment; the transverse

* Contributions from the Seto Marine Biological Laboratory, No. 201.

Publ. Seto Mar. Biol. Lab., III (1), 1953. (Article 4) 


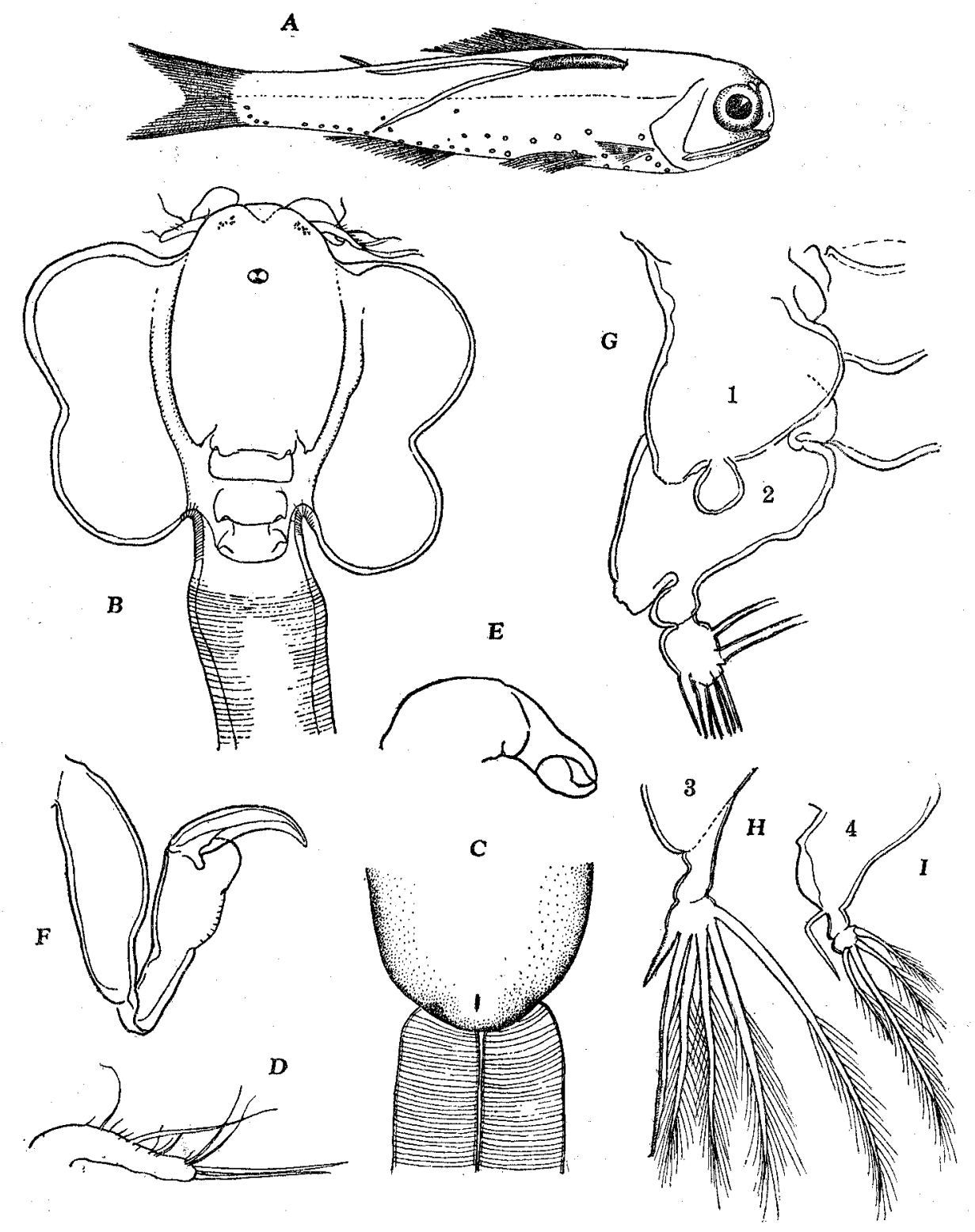

Fig. 1. Lernaeenicus quadrilobatus n. sp.

A, female (holotype) parasitic on Diaphus coeruleus Klunz. $\times 1.3 . \mathrm{B}$, dorsal view of cephalothorax. $\times 27$. C, dorsal view of posterior part of trunk. $\times 18 . \mathrm{D}$, first antenna. $\times 80$. E, second antenna. $\times 80 . \mathrm{F}$, second maxilla. $\times 150 . \mathrm{G}$, first and second legs on the right side, the outer rami being missing. $\times 150 . \mathrm{H}$, third leg. $\times 150$. I, fourth leg. $\times 150$. 
posterior margin of each segment is also fairly well marked out. Neck slender, curved $6.3 \mathrm{~mm}$ long, somewhat contracted at the anterior end where the swimming legs are attached, and a little swollen at a point about one-third the length of the neck from its posterior end. Trunk cylindrical, straight, $9 \mathrm{~mm}$ long by $2 \mathrm{~mm}$ wide, dull brown, slightly increasing in diameter posteriorly. Abdomen rudimentary, forming a mere hemispherical protuberance. Egg strings $16 \mathrm{~mm}$ long and $0.6 \mathrm{~mm}$ wide; eggs uniseriate, strongly flattened.

Appendages: First antenna cylindrical, $0.28 \mathrm{~mm}$ long, directed obliqueiy backwards, indistinctly separable into three portions, with a few long and many fine setae along anterior margin, two long setae at tip and four more subterminally. Second antenna two-segmented, with its stout base projecting forward beyond base of first antenna, second segment chelate. Fringed chitinous margin of mouth cone notched medially at anterior end, $0.275 \mathrm{~mm}$ in diameter. First maxilla rather slender, tipped with two unequal setae. Second maxilla threesegmented, basal segment stout, longer than middle segment, terminal segment forming a claw shorter than middle segment. Of the four pairs of swimming legs the first two are biramous and the last two uniramous. All rami twosegmented. Unfortunately most of the rami are missing except for the right inner ramus of the second leg, whose terminal segment bears six plumose setae along distal and inner margin. Terminal segment of third leg with two unequal, pectinate spines and four plumose setae, that of fourth leg with four plumose setae only.

This species is distingtished from any of the known members of the genus by the cephalothorax possessing two large rounded lobes on each side. The specific name refers to this character. So far as we are aware, all the known species of Lernaenicus are usually furnished with one pair of horn-like lateral projections on the cephalothorax.

\section{LITERATURE}

BRIAN, A. G. G. 1906. Copepodi parassitici dei pesci d'Italia.

LEIGH-ShARPE, W. H. 1927. Report on a parasitic copepod of Atherina pinguis (Lernaeenicus cereberus sp. n.). Trans. Zool. Soc. London, 22, Pt. 2.

1934. The Copepoda of the Siboga Expedition. Part II. Commensals and parasitic Copepoda. Siboga-Expeditie, Mon. 29b.

1935. Two copepods (Lernaeenicus) parasitic on Clupea. Parasitology, 27, No. 2.

Kirtisinghe, P. 1932. Two new parasitic copepods from Ceylon. Parasitology, 24, No. 4. SCoTT, T. \& A. SCotT 1913. The British parasitic Copepoda. Ray Society, London.

WILSON, C. B. 1932. The copepods of the Woods Hole region, Massachusetts. U. S. Nat. Mus., Bull. 158.

YAMAGUTI, S. 1939. Parasitic copepods from fishes of Japan. Part 5. Caligoida, III. Volumen Jubilare pro Prof. Sadao Yoshida, 2. 